\title{
Exemplary Paternalism: A Consideration of Confucian Models of Moral Oversight
}

\author{
Sarah Flavel \\ School of Humanities, Bath Spa University, Bath, UK \\ s.flavel@bathspa.ac.uk \\ Brad Hall \\ King's College London, University of London, London, UK \\ brad.robert.hall@gmail.com
}

\begin{abstract}
In this article we examine Classical Confucian political thinking through the lens of paternalism. We situate Confucianism amid contemporary models of paternalism to show that Confucianism can be understood as a soft form of paternalism regarding its method. Confucianism stresses cultivation of the people by moral exemplars to guide the people to act in ways that are in their own best interests. This is in contrast to use of law and punishment as a deterrent of unwanted behaviours of the people. We demonstrate that Confucian paternalism does not advocate for a static top-down structure of governance that is incapable of reform, underscoring its non-authoritarian ideal. We do this by stressing the vital upward momentum constituted in general cultivation of the wider population utilizing $l i$ (rituals). The picture that emerges from an examination of Confucian political thought through the lens of paternalism is what we name "exemplary paternalism."
\end{abstract}

\section{Keywords}

paternalism - Confucian political philosophy - political paternalism - Confucian politics - exemplary paternalism 


\section{Introduction}

In this article, we consider how examining Classical Confucian political thinking through the lens of paternalism can offer valuable interpretive and comparative insights into the nature of Confucian philosophy. Further, we aim to show how such consideration of early Confucian thinking can contribute to general discourse on paternalism. This exploration is especially useful because, we would suggest, the underlying principles of paternalist thinking can be identified as a common thread across most of the dominant Classical schools of Chinese political thinking. ${ }^{1}$

Confucianism as a school of thought spans over two thousand years and has undergone many transformations. In what follows, we use the term "Confucianism" to refer mainly to the philosophy of The Analects of Kongzi (Confucius). To a lesser extent we also draw on the writings of two other important early Confucian thinkers, Mengzi and Xunzi, to support our reading. By doing this we do not mean to suggest that there are not important differences and disagreements between these figures. Where relevant, we highlight these. Further, in the following we limit our focus to the early Confucian ideal image of political arrangements and societal structures rather than the more pragmatic, and often less utopic, theories for application given in certain Confucian thinkers. We do not mean, with our assessment, to suggest that this ideal form has been fully exhibited in any particular concrete historical periods of supposedly Confucian social or political structures. ${ }^{2}$

Gerald Dworkin defines paternalism as "the interference of a state or an individual with another person, against their will, ... defended or motivated by a claim that the person interfered with will be better off or protected from harm." ${ }^{3}$

Paternalism is unpopular in contemporary discourse, often being identified as the hallmark of authoritarian and totalitarian regimes. Any sign of paternalist activities being undertaken by a government therefore tend to lead to

1 This present work follows on from our previous research into the "maternalist" principles underlying the Daodejing (a classical Chinese foundational text of the school of thought known as Daoism): Sarah Flavel and Brad Hall, "State Maternalism: Rethinking Anarchist Readings of the Daodejing," Dao 19, no. 3 (2020): 353-369.

2 Joseph Chan provides an excellent discussion regarding these different currents of thinking in Confucianism and how the two interact; Joseph Chan, Confucian Perfectionism: A Political Philosophy for Modern Times (Princeton: Princeton University Press 2014), 1-23.

3 Gerald Dworkin, "Paternalism," The Stanford Encyclopedia of Philosophy (Summer 2020 Edition), ed. Edward N. Zalta, https:/plato.stanford.edu/archives/sum2o2o/entries/paternalism/ (accessed August 31st, 2020). 
derogatory claims that they are movements towards a "nanny state" or worse. Referring to the association of paternalism with authoritarian regimes, Sarah Conly aptly explains that: "Even if we remind ourselves that paternalistic measures must, by definition, be beneficent in intent, which the Nazis and Khmere Rouge obviously were not, it is not much of a comfort." 4

In fact, many would regard the development of human rights and associated individual freedoms as a long-fought victory over paternalism. ${ }^{5}$ The birth of the notion of the rational individual capable of reasoning and thinking for themselves brought with it a distrust of authority. Due to the unpopularity of paternalism, the term is not often understood to be a useful diagnostic concept, let alone framed as a positive political and social theory to be supported and implemented. As Michael Barnett notes, "more often than not, it [paternalism] is hurled as an accusation and allegation."

However, directly equating paternalism with authoritarianism is both abstractly and concretely inaccurate. Paternalist models of social control arguably inform the activity and legislation of all modern states in both the Western and Asian contexts. As Christopher Wolfe argues:

Paternalism, from one point of view, is simply unavoidable. It would be an illusion to believe that the form and content of the law - all law, in liberal regimes as well as others - do not have a powerful influence on the lives of many human beings, subtly shaping their attitudes about what a good human life is. ${ }^{7}$

Generally speaking, paternalism is a characteristic function of the legal system where we benefit from a wide variety of laws designed to protect us from our own potentially harmful behaviors. Paternalist mechanisms can be seen in laws that instruct people to wear seatbelts in cars whether they want to or not, in those that compel parents to take their children to school, and those that prohibit people from carrying guns just because they would like to do so. It can also be seen in more indirect forms in the raising of taxes and prices on harmful products such as cigarettes to deter people from buying them. It can also of course be seen outside of the legal system in anti-tobacco and anti-drink

4 Sarah Conly, Against Autonomy: Justifying Coercive Paternalism (Cambridge: Cambridge University Press 2013), 24.

5 Michael N. Barnett, "Introduction," in Paternalism Beyond Borders, ed. Michael N. Barnett (Cambridge: Cambridge University Press, 2017), 7.

6 Barnett, "Introduction," 5 .

7 Christopher Wolfe, "Liberalism and Paternalism: A Critique of Ronald Dworkin," The Review of Politics 56, no. 4 (Fall 1994): 639. 
driving advertising campaigns funded by the government that seek to influence people's perspectives and thereby inform their behaviors. All these paternalist practices are common and even subject to wide approval by populations in modern liberal democracies. To suggest that Western governments are substantively non-paternalist is descriptively inaccurate.

Various recent historical events in the West underscore further need for a reappraisal of views on paternalism and its role in legitimate governance. Populist movements in the election of Donald Trump and the UK vote on Brexit have increasingly underscored the dangers of trusting direct democratic mechanisms in deciding what is in the best interests of a nation. These events show how easy it is for public opinion to drastically veer away from the insights provided by those with relevant expertise in, for example, economic projection. Globally, the outbreak of Covid-19 has also brought to the foreground the benefits of paternalist tools in relation to those governments who enforced harsher lockdowns earlier upon their citizens and seemingly appear to have had better outcomes in response to the crisis, at least in terms of controlling the virus itself to date. Overall, such phenomena lead us to re-think whether Eamon de Velera might have been right (at least in spirit) in his famous but controversial paternalist claim that: "The majority have no right to do wrong."

Paternalism, as an approach to governance, has two closely related underlying principles. Firstly, that if people are left to their own devices, they have tendencies not to know what is in their own best interests and are therefore not likely to act in their own best interests. Secondly, that the state, if properly organized, can be in a better position to know what is in the best interest of the people and to make certain decisions on their behalf. Classical Confucian political philosophy holds to both underlying principles of paternalism, making paternalism an apt term to use when discussing Confucian ideas of political governance. We are not the first to apply paternalism to Confucian thinking. However, in existing scholarship there has been a lack of attention paid to the variety of definitions and models of paternalism in contemporary literature and how these relate to the Confucian model. Such oversight can serve to conceal the unique positive elements of Confucian philosophy and particularly those that can enhance Western discourse on paternalism. Further, it can lead to the negative connotations of paternalist systems of oversight being transposed onto our understanding of Confucianism, and in so doing, support an authoritarian reading.

8 As quoted in John Hutchinson, Nationalism and War (Oxford: Oxford University Press 2017), 169 . 
Our reading and aims in this paper do share some degree of similarity with the work of Joseph Chan who describes Confucian political thinking as a form of "perfectionism." Chan outwardly rejects the label of paternalism because of, among other things, its authoritarian connotations. ${ }^{9}$ Whilst we draw on Chan to support some elements of our own work, we disagree fundamentally on this point about the overall characterization of Confucianism in paternalist terms, which has non-trivial consequences. This will be made clear after further advancement of our argument.

Before going on to dispute such a reading, Sor-hoon Tan notes that "Confucianism has often been treated as an authoritarian philosophy that exalts the absolute authority of rulers over subjects, of fathers over sons, and of husbands over wives."10 For example, Shaun O'Dwyer, who discusses Confucianism in a framework of paternalism, shows some sympathy for this reading. Referring to the philosophy of Mengzi, an early Confucian thinker second in importance only to Kongzi himself, O'Dwyer endorses a top-down interpretation of Confucian rulership by suggesting that in Confucianism "There is indeed a good deal of tolerance for 'one way obedience."'11

To define Confucianism as authoritarian would be an unfair judgment on several counts, but especially because Confucian thinkers believe that using coercion and force of law as a primary method of control is an inferior method of overseeing and even directing the behaviors of the people. ${ }^{12}$ Kongzi himself expressly thinks of legalist frameworks as self-defeating because they fail to encourage reliable moral behaviors among the population over time. Instead, the attempt to "control" popular behavior is enacted through a long-term system of virtue cultivation, in which Confucianism, instead of forcing people to behave in a manner deemed best by leaders, encourages the general moral cultivation of the people such that they should want to behave in a manner that coheres with general social harmony and their own best interests. In this sense the Confucian brand of paternalism is designed as a corrective to the first principle of paternalist thinking: that if people are left to their own devices they have tendencies not to know what is in their own best interests and are therefore not likely to act in their own best interests. The Confucians believe it possible that remedial measures can correct this problem.

9 Chan, Confucian Perfectionism, 44.

10 Sor-hoon Tan, "Authoritative Master Kong (Confucius) in An Authoritarian Age," Dao 9 (2010): 137 .

11 Shaun O'Dwyer, "Epistemic Elitism, Paternalism, and Confucian Democracy," Dao 14 (2015): 40-41.

12 Chan, Confucian Perfectionism, 13-14. 
Dworkin's definition, mentioned above, suggests that paternalism can be understood only in terms of outwardly forcing people to act or not act in certain ways against their will. Confucianism challenges this definition and can be understood as a softer form of paternalism in that it promotes exemplary virtuous leadership and moral education of the masses over force and rule by law. In the following section of this paper we support a broader and less pejorative definition of paternalism, as given by Barnett, that seeks to "[resurrect] the analytical utility of the concept."13 The definition is better suited to Confucianism as it integrates those paternalist activities including positive instances where a person, or society in general, is willing to give authority over to those deemed more knowledgeable in order that they can make decisions on their behalf. We look at some contemporary theories and models that wish to positively utilize paternalist methods that do not rely on force, highlighting their similarities and differences to the Confucian model.

We then move on to examine Confucianism more closely through the lens of paternalism, engaging with and building upon scholars who have undertaken projects in this area. We do this in four steps. Firstly, we give a brief overview of the historical context of early Confucianism. Secondly, we demonstrate that Confucian paternalism is constituted in governance by moral exemplars in line with the will of the people and that therefore does not advocate for authoritarian rulership. Thirdly, we contrast Confucianism with another early Chinese political philosophy known as legalism, which holds law and punishment to be the best deterrent of unwanted behaviors of the people.

Finally, we demonstrate that Confucianism does not advocate for a static top-down structure of governance that is incapable of reform, further underscoring its non-authoritarian ideal. We do this by stressing the vital upward momentum involved in general cultivation of the wider population. In the Confucian ideal, paternalism is enculturated into the people at all levels through exemplary leadership and education in li (rites, rituals, and codes of conduct governing social relations). This encourages the development of paternalist sentiment among the population in general who are expected to take on paternal roles towards those in their care. This means that, ideally speaking, the people can gain the skills and moral sentiments necessary to go on to be exemplary virtuous leaders themselves. Without this upward movement, grounded in moral education, the ability to sustain exemplary moral governance would not be possible. The aim of Confucianism is to create morally cultivated dynamic individuals who will eventually have the capacity to govern and transform culture and society so that stability of the state and the welfare

13 Barnett, "Introduction," 5 . 
of the people is secured through changing social, cultural, political and geographical climates. In theory at least, such participation in the moral future of society is to be made available to all citizens.

The picture that emerges from an examination of Confucian political thought through the lens of paternalism is what we name "exemplary paternalism." This an image of the relationship between the ruler and subjects (or state and its people) that attempts a balance between top-down oversight and emphasis on cultivation of political life from the bottom up. In this sense Confucianism cannot be said to overemphasize the position of the leader at the expense of the integrity of and regard for their subjects below or that it excludes citizens from active participation.

In concluding we argue that not only is it appropriate to define Confucianism as a form of paternalism but that the unique aspects of Confucian exemplary paternalism make it able to contribute towards the debate as to definition. This further allows for Confucianism to contribute towards projects that seek to utilize paternalism in addressing issues of contemporary politics in positive ways that are not simply dismissed as excessively authoritarian.

\section{$2 \quad$ Defining Paternalism}

Determining the boundaries of "paternalism" is a contested issue. At what point can we claim particular state actions to be paternalistic (and to what extent are we willing to give up our rights and freedoms in order to allow for such practices)? Danny Scoccia argues, it is "a common mistake ... to define 'paternalism' in a way that limits the means to coercive ones."14 Dworkin extrapolates his definition of paternalism by saying that at the very least it "involves some kind of limitation on the freedom or autonomy of some agent and it does so for a particular class of reasons. ${ }^{15}$ When such laws and rules are

... justified solely on the grounds that the person affected would be better off, or would be less harmed, as a result of the rule, policy, etc., and the person in question would prefer not to be treated this way, we have an instance of paternalism. ${ }^{16}$

14 Danny Scoccia, "In Defense of Hard Paternalism," Law and Philosophy 27, no. 4 (July 2008): 353 .

15 Dworkin, "Paternalism."

16 Ibid. 
Dworkin's definition certainly implies that for any activity to qualify as paternalist it must be coercive, forceful and against the will of the person being interfered with. Such definitions do not allow for more subtle instances of paternalism where decisions are made for others (with or without their knowledge) yet perhaps with their full or implicit support. Dworkin's approach in some sense therefore assumes that those ruled by paternalist governance would always rather not be treated this way or that to disagree with what one is asked to do is integral to how we define a paternalist action. Thus, we find such a definition problematically pejorative.

When paternalism is understood this way, its sub-definitions likewise are produced in this problematic framework. For example, Dworkin outlines a distinction between softer and harder forms of paternalism, claiming that soft paternalism allows for intervention only in cases where someone is not fully aware of the nature and consequences of their actions (and is therefore not understood to be acting freely). ${ }^{17}$ In contrast, hard paternalism allows for intervention even against voluntary and fully informed actions when such actions are deemed not in the person's best interest. An obvious example would be that under hard paternalism we can stop a person drinking poison, even if they are doing so fully aware of the consequences. Soft paternalism would require that they are somehow unaware or incapacitated in their decision making.

We therefore see that the distinction between hard and soft tends to be made solely on the grounds of difference in views as to when it is acceptable to force someone against their will to change their behavior. Conversely, the distinction can be understood in terms of how much freedom is given to individuals to make their own decisions.

We describe Confucian paternalism as soft, but we do not mean it in the sense above. The distinction we make between a hard and soft paternalism is instead in reference to method. Confucianism is a soft form of paternalism but not in relation to the amount of freedom it affords citizens. The distinction to be made is between the method of hard paternalism in which force of law is seen as the most efficacious way of getting the people to behave in ways conducive to their own best interests and the interests of the state, and the alternative method of soft paternalism in which virtuous leadership and moral cultivation of the people are understood to be the most efficacious tools. In other words, soft paternalism may aim at the same results but with an entirely different methodology. This is how the terms hard and soft can more meaningfully be used when discussing early Chinese paternalism, in which the issue of promoting maximal individual freedom is less of a central concern.

17 Ibid. 
A broader definition of paternalism is needed to incorporate the soft paternalism of Confucianism. Barnett gives an alternate definition of paternalism to that of Dworkin:

Paternalism is the attempt by one actor to substitute his judgment for another's on the grounds that it is in the latter's best interests or welfare. ${ }^{18}$

As Barnett explains, by focusing on the substitution of judgment over use of force, this alternative definition is thus able to incorporate those paternalist activities that are not straightforwardly framed in terms of one actor forcing another actor to do something they would otherwise not do or explicitly do not want to do (or stopping them from doing something). Such activities occur

... when institutions set an agenda that removes some possibilities from the menu of choice and from discussion. It occurs when actors occupy roles that give them the authority and duty to act in someone else's best interests. ${ }^{19}$

An example might be the content of a national curriculum for students being determined by a government body. Although backed by law and having mechanisms for people to voice their disagreement, most are happy to hand authority over to professionals who will make these decisions that may have significant impacts on their children's education and the shape of future society. Just because people agree on this system, in which one allows for judgment to be made on their behalf, does not mean it is not a paternalist gesture. Children and their parents, broadly speaking, are not directly empowered to make choices regarding the content of their schooling. The example of education is an apt one as universal education (including moral education) is a key element of cultivating the people in early Confucianism. ${ }^{20}$

There are, in fact, plenty of examples of people in liberal democracies recognizing their inability to make a sound judgment and going on to give up certain rights and abilities to make certain choices and perform certain actions, with a preference that someone else should make judgement in their place. This can be seen in people admitting themselves to psychiatric institutions, or drug rehabilitation clinics, when they fear that they cannot trust themselves. It can also be seen outside of health institutions in examples such as compulsive

18 Barnett, "Introduction," 13.

19 Ibid.

20 Mencius, trans. D.C. Lau (Hong Kong: Chinese University Press 2003), 3A4, 115. 
gamblers voluntarily signing up to blacklists that bar them from entering casinos under pain of possible penalty. ${ }^{21}$ These people acknowledge that they are not inclined to take actions in their own best interest and therefore request a degree of control over their own future activities by an external party. The point being that paternalism does not necessarily entail discord between those that make decisions and those on whose behalf they are deciding. This is especially important in the case of a Confucian model of governance, that would expressly want to avoid a clash between the leader and the people despite the overall acceptance that the leadership can and should usually be in such a position of decisive authority.

One of the further advantages of a definition that focuses on substitution of judgment is that it helps to remove the inherently negative authoritarian connotations from the concept. As such, the definition allows for a more sober analysis that does not immediately equate Confucianism with authoritarianism and thus tend toward the merely pejorative.

To argue for a reading of Confucianism as non-authoritarian, Tan wishes to downplay its paternalist elements:

In coercing others for their own good, paternalism is authoritarian.... Even if one concedes that there is a tendency to paternalism in Confucianism, one could still maintain that paternalism could not be pushed too far on Confucian grounds because its concern is moral transformation which could not be brought about by force alone. ${ }^{22}$

Likewise, Chan wishes to avoid using the term to understand Confucianism saying that paternalism "is commonly associated with the use of coercion by the state to promote the good of its citizens." ${ }^{23}$ However, the negation of Confucianism as a paternalism is made here on the basis that paternalism is authoritarian. This is in line with the more limited definitions of paternalism such as those of Dworkin. In fact, Tan can here be seen to be using a notion of soft paternalism along the lines that soft paternalism avoids interfering in personal freedoms as far as possible rather than it being softer in method. This is further highlighted when she goes on to say that in Confucianism:

21 Robert Ladouceur et al., "Responsible gambling: a synthesis of the empirical evidence," Addiction Research and Theory 25, no. 3 (2017): 229-230.

22 Tan, "Authoritative Master Kong," 141.

23 Chan, Confucian Perfectionism, 44. 
Force could at best be used as a temporary measure, and only if there is reason in each specific case to believe it would contribute to an appreciation of the good aimed at, and eventually voluntary compliance would render force unnecessary. ${ }^{24}$

Whilst we do not disagree that this is indeed a part of Confucian paternalism, we argue that this is only a small aspect of it. By aligning paternalism with authoritarianism, Tan is forced to downplay the paternalist aspects of Confucianism. This opens her argument up to criticism that it does not honestly represent these aspects of Confucian political philosophy. However, if we understand paternalism in the broader sense of substitution of judgment then the paternalist tendencies of Confucianism can be brought to the foreground and even celebrated (even when being critiqued). The strength of paternalist methods of governance that do not rely solely on force and coercion are made clearer when we recognize them as such and accept their background views as to the validity of a paternalist approach.

There are contemporary definitions and forms of paternalism that attempt to take account of the fact that paternalism can present itself in different ways using methods other than force of law and thus can be referred to as soft in the sense that we wish to use the term. For example, positive (as opposed to negative) paternalism focuses on providing incentives for people to make better choices such as subsidies for using leisure centers to encourage sporting activities to improve health. ${ }^{25}$ What is important to highlight here is that such methods not only encourage people to make better choices but also allow people to be actively involved in their own betterment. In a not dissimilar way, Confucian paternalism requires that the people be engaged in their own cultivation.

Another wave of new thinking that seeks to demonstrate how paternalism can be used positively in free democratic societies was brought to the foreground in the book Nudge: Improving Decisions About Health, Wealth and Happiness by Cass Sunstein and Richard Thaler. ${ }^{26}$ This is known as liberal paternalism. Rather than removing choices from people by force or by increasing the cost of making certain decisions (raising the price of cigarettes for example), they suggest that people can be nudged into making the better choices by changing how those choices are presented. For example, by placing healthy

\footnotetext{
24 Ibid.

25 Ryan J. Thomas, "In Defense of Journalistic Paternalism," Journal of Media Ethics 31, no. 2 (2016): 9 .

26 Richard H. Thaler and Cass R. Sunstein, Nudge: Improving Decisions About Health, Wealth and Happiness (New Haven: Yale University Press 2009).
} 
food at the front in a cafeteria and by shining a light onto it, people are encouraged to make the healthy choice. Changing opt in to opt out systems for pensions and organ donation can increase uptake. ${ }^{27}$ By altering the architecture of choice through which people make their decisions people can be encouraged to make better choices.

Thaler and Sunstein define a nudge as "any aspect of the choice architecture that alters people's behavior in a predictable way without forbidding any options or significantly changing their economic incentive." ${ }^{28}$ Some criticize nudging for harnessing cognitive biases in people's decision making. For example, opt out systems cash in on the cognitive bias to not spend effort to change something that is already in place. It is also criticized for not being transparent and for manipulating people without their knowledge. ${ }^{29}$

Liberal paternalism can also be criticized on the grounds that it is not sufficiently paternalist to warrant the name. Christopher Snowdon argues that:

The most damning criticism of the nudge project is not that it is illiberal, but that it is insubstantial in the context of the big issues of government. If one strips out all of the nudges that are not paternalistic [they treat the individual as fully competent decision makers or do not directly benefit the individual], not libertarian and not trivial, there is little left of the libertarian paternalist agenda. It is precisely because Thaler and Sunstein are reluctant to use state coercion that the implications of nudge theory for public policy are so limited. ${ }^{30}$

By trying to retain the freedom of the individual, liberal paternalism becomes so liberal that it does not live up to the name paternalism anymore, at least not in regard to a system of governance. In both positive and liberal paternalism, the focus on incentive generally removes the aspect of deterrent. More severe interventionist measures enforced by law are necessary to deal with the more difficult situations.

Having briefly outlined some of the issues surrounding definition, we are now in a position to more closely examine Confucianism as a form of paternalism under the broad definition given by Barnett that has a focus on the substitution of judgment. As will be explained in more detail in the following

27 Dworkin, "Paternalism."

28 Thaler and Sunstein, Nudge, 6.

29 Dworkin, "Paternalism."

30 Christopher Snowden, Killjoys: A Critique of Paternalism (London: Institute of Economic Affairs 2017), 24. 
section, Confucianism shares some similarities with positive and liberal paternalism in that it seeks to guide and encourage rather than force one to act or not act. However, Confucianism does not hold the autonomy of the individual to be of the highest value and therefore it recommends a much more radical method of inculcating the people into a moral outlook that molds them into virtuous citizens. By doing this, Confucianism retains a power of deterrence in that the people are unwilling to commit acts that are not morally upstanding due to a sense of shame. It does not make use of defects in the decision making of people but rather appeals to their better nature and their ability to make better judgment. Furthermore, Confucianism is transparent about its paternalism regarding its methods of changing the people's behavior through moral cultivation. It is a soft form of paternalism but one that is far more resilient to the criticisms given above, one we term "exemplary paternalism."

\section{3}

\section{Confucian Exemplary Paternalism}

In some recent scholarship, the term "paternalism" has been used when discussing classical Confucian political philosophy. Gregory Fairbrother goes so far as to suggest that "each Chinese regime since the late imperial period has claimed legitimacy on the basis of its paternalistic character." ${ }^{31}$ Whilst overstated and overlooking the strong influence from other schools of thought, Fairbrother identifies the roots of this paternalism in classical Confucian thought when he says that "Paternalism is not completely synonymous with Confucianism, but it does have its primary basis in the classical Confucian works of Confucius himself, Mencius and Xunzi." ${ }^{32}$ These prominent Confucian thinkers lived in the politically fragile times known as the Spring and Autumn and Warring States periods.

Imperial China begins with the Qin dynasty (221-206 BCE). The founding of the Qin dynasty ended the Spring and Autumn and Warring States periods $(722-221 \mathrm{BCE})$. This was a time of great political upheaval and change that saw the demise of the feudalistic hierarchy of the former Zhou dynasty (1122-221 BCE) and the rise of independent feudal states. It had been common practice for the Zhou kings to enfeoff their relatives and afford them some power, but these familial bonds were now weakening. Contractual and ritual

31 Gregory P. Fairbrother, "The Chinese Paternalistic State and Moral Education," in Citizenship Education in China: Preparing Citizens for the "Chinese Century," ed. Kerry J. Kennedy, Gregory P. Fairbrother, and Zhao Zhenzhou (London: Routledge, 2014), 13.

Fairbrother, "The Chinese Paternalistic State," 14. 
associations between rulers and ruled that had ensured the stability of their relationship were becoming unstable. Infighting within states and war between newly independent states was made inevitable by population growth and limited resources. ${ }^{33}$ In the philosophical language of the time, the Way (Dao) does not prevail in the world.

The turmoil of the Spring and Autumn and Warring States periods gave rise to many political issues and saw a flourishing of diverse political philosophies. Based on the experience of political and cultural upheaval during this time a number of different schools presented themselves as offering alternative answers to the question of how to cohere society and the best models of political and moral oversight. For this reason, the era is often typified as the Hundred Schools period of Classical Chinese philosophy. ${ }^{34}$

Generally speaking, the primary concerns across the varying philosophies of the time can be subsumed under the broader question of how to return stability and harmony to the political and social landscape. As Tongdong Bai explains "when the old political structure no longer has relevance to the new reality, ... a new regime is desperately needed." ${ }^{35}$ Although only posthumously gaining his position at the center of Chinese philosophy, this is the historical context in which the ideas of the Classical thinker Kongzi were established and began to gain traction.

A key feature of a Confucian paternalist framework is rule by moral exemplars. ${ }^{36}$ Kongzi makes no proposal to do away with hierarchical structures in which a single authority sits at the top with governors and ministers of lesser authority surrounding him, overseeing the general populace below.

Chapter 1.2 of the Analects (a collection primarily of the teachings of Kongzi, who wrote nothing down himself, and some other Confucian thinkers) reads:

It is a rare thing for someone who is filial to his parents and respectful to his older brothers to defy superiors to be keen on initiating rebellion. Exemplary persons concentrate their efforts on the root, for the root having taken hold, the Way will grow therefrom. Being filial to one's parents and being respectful to one's older brothers is the root of humanity! ${ }^{37}$ Books), 17-18.

34 Karyn N. Lai, An Introduction to Chinese Philosophy (Cambridge: Cambridge University Press 2008), 3.

35 Bai, China, 21.

36 Fairbrother, "The Chinese Paternalistic State," 18.

37 Quoted in Bai, China 36. 
Bai notes that this passage "suggests that communal and political relations are analogous to and should be modelled on familial relations." ${ }^{38}$ Roger Ames and Henry Rosemont explain that the Confucian worldview promotes the family as "the pervasive model of order." 39

In the West, paternalism utilizes a metaphor of the family, in which the parents are more knowledgeable and experienced than their children and need to make decisions on their behalf for their protection and betterment. In Confucianism, however, (and present in much early Chinese thinking), this can be understood to have literal connotations. Jiwei Ci claims that, "In a sense, the analogy is more metaphorical than literal, but it almost can be taken literally through the influence of ideology, in which the ruler is the father of his subjects." 40 With the rulers understood as the fathers and mothers and the people their children, paternalism is an attractive framework through which to study Confucianism. Confucian leaders are literally meant to be wiser in terms of the widest interests of the population.

However, the role in the family that you inhabit is determined by circumstance. Doh Chull Shin tells us that in politics, the early Confucians were advocating for a "merit-based system [that] enabled the most talented to rise to the highest offices, replacing the rule by hereditary aristocracy."41 Such a hierarchy is not intended to imply aristocratic elitism and Confucius is keen to promote those who are deserving of promotion based on worthiness rather than heredity.

For Kongzi, the legitimacy of such a rule is not to be found in birthright. It is not God-given. Furthermore, authority is not to be assumed forcefully through military might. In the ideal vision, political legitimacy rests solely in leadership that embodies the virtue of ren (benevolence/humanness) as an overarching characteristic of virtuous leadership that contains within it numerous other underlying virtues. Shin describes this as "a form of benevolent paternalism" and a "paternalistic meritocracy." 42

$38 \quad$ Ibid.

39 Roger T. Ames and Henry Rosemont, Jr., "Introduction," in The Analects of Confucius: A Philosophical Translation, trans. Roger T. Ames and Henry Rosemont, Jr. (New York: Ballantine Books 1998), 58 .

40 Jiwei Ci, "The Confucian Relational Concept of the Person and Its Modern Predicament," in Personhood and Healthcare, eds. David C. Thomasma, David N. Weisstub, and Christian Herve (Dordrecht: Kluwer 2001), 155 .

41 Doh Chull Shin, Confucianism and Democratization in East Asia (Cambridge: Cambridge University Press), 114.

42 Shin, Confucianism and Democratization, 146 and 137. 
Regarding who these rulers should be, Kongzi appropriated the term junzi, which was a title literally meaning a lord/prince's son. Working to instill morality as the legitimacy for rulership, Kongzi imbues the term with "aesthetic, moral, and spiritual characteristics." ${ }^{33}$ The junzi are those who have travelled far along the path of moral cultivation, who work tirelessly to realize ren and to gather knowledge in themselves and their actions, and who truly feel love towards the people. They are knowledgeable and learned in history, tradition, ritual, and codes of conduct. Geir Sigurdsson succinctly describes a junzi as "an exemplary person, whose experience and wisdom, communicability and openness, social sense and acquired personal charisma provide him or her with the ability to transform the immediate social environment." ${ }^{44}$ They serve as role models to the people. The junzi are those competent enough to govern. Above even the junzi are the sages. Kongzi tells us that the junzi stand in awe of the words of the sage. ${ }^{45}$ Kongzi says, "How majestic they were - Yao and Shun reigned over the world but did not rule it." ${ }^{\text {"6 }}$ By claiming that these real or imagined sage rulers reigned but did not rule, Kongzi is highlighting their exemplary moral leadership that did not require oppressive force.

As benevolent rulers, the junzi and the sages are responsible for overseeing the "economic prosperity" and "physical security" of the people. ${ }^{47} \mathrm{O}$ 'Dwyer further expands on this exemplary leadership by highlighting the "epistemic elitism and paternalism that is central to the early Confucian thought." ${ }^{\prime 4}$ Epistemic elitism is a part of Confucian paternalism constituted by such morally and intellectually elite governors making decisions deemed to be in the best interest of the people without need to divulge information to the people about how those decisions are made. Although the ruler is humble and willing to consult the people to make an informed decision, this decision making is beyond the realm of the ordinary people. Kongzi says, "when the way prevails in the world, the common people do not debate affairs of state."49

Both Shin and O'Dwyer use a key passage from the Mencius where he looks to an example from the past to argue for a division of labor. Those of superior

43 Ames and Rosemont, "Introduction," 6o-61.

44 Geir Sigurdsson, "Confucian Philosophy as a Universal Approach to Integrated Living: A Contemporary Interpretation," in Differences in Identity in Philosophy and Religion: A Cross-Cultural Approach, ed. Sarah Flavel and Russell Re Manning (London: Bloomsbury 2020), 32.

The Analects of Confucius: A Philosophical Translation, trans. Roger T. Ames and Henry Rosemont, Jr. (New York: Ballantine Books 1998), 16:8, 198.

46 The Analects of Confucius, 8:18, 124.

47 Shin, Confucianism and Democratization, 115.

48 O'Dwyer, "Epistemic Elitism," 51.

49 The Analects of Confucius, 16:2, 197. 
knowledge and skill perform the greater acts on behalf of the populace so that they may perform the smaller duties. In passage $3 \mathrm{~A}_{4}$ Mengzi says:

If everyone must make everything he uses, the Empire will be led upon a path of incessant toil. Hence it is said, 'there are those who use their minds and there are those who use their muscles. The former rule; the latter are ruled. Those who rule are supported by those who are ruled.'

In the time of Yao, the Empire was not yet settled. The Flood still raged unchecked, inundating the Empire; plants grew thickly; birds and beasts multiplied; the five grains did not ripen; birds and beasts encroached upon men, and their trail criss-crossed even the Central Kingdoms. The lot fell on Yao to worry about this situation. He raised Shun to a position of authority to deal with it. Shun put Yi in charge of fire. Yi ringed off the mountains and valleys and set them alight, and the birds and beasts went into hiding. Yu dredged the Nine Rivers, cleared the courses of the Chi [Ji] and the T'a [Ta] to channel the water into the sea, deepened the beds of the Ju $[\mathrm{Ru}]$ and the Han, and raised the dykes of the Huai and the Ssu [Si] to empty them into the river. Only then were the people of the Central Kingdoms able to find food for themselves..$^{50}$

This passage makes clear that there is a distinction between ruler and ruled that is based upon ability and wisdom. Without the wisdom and actions of the virtuous rulers, the people in the story would likely live harsh and difficult lives. Mengzi tells us that if everyone only looks after themselves, then people will not be able to enact large scale projects that will have great benefit for all the people. The people are key to enacting these projects, but they are not knowledgeable or virtuous enough to design them in the interests of others. Kongzi says that "The common people can be induced to travel along the way, but they cannot be induced to realize it." ${ }^{51}$ Similarly, Mengzi says that "The multitude can be said never to understand what they practice, to notice what they repeatedly do, or to be aware of the path they follow all their lives." ${ }^{\prime 2}$ Xunzi is perhaps more optimistic in this regard, holding the view that anyone has the potential to become a sage. ${ }^{53}$

$50 \quad$ Mencius, $3 \mathrm{~A} 4,115$.

$5^{1} \quad$ The Analects of Confucius, 8:9, 122.

$5^{2}$ Mencius, $7 \mathrm{~A}_{5}, 289$.

53 Xunzi: Basic Writings, trans. Burton Watson (New York: Columbia University Press), 170. 
In the passage from the Mengzi it is also seen that the ruler grants authority to those deemed able to take on great responsibility, i.e. based on merit. This is how the ruler can ensure the aptitude of those in the government and the government's success. Initially, Yao gives authority to Shun. As the legend goes, Yao would go on to cede the Empire to Shun to whom he was unrelated. ${ }^{54}$ Shun would go on to become a legendary sage ruler himself.

Kongzi uses a beautiful analogy to describe a true ruler and the lofty and authoritative position they hold that gives them almost cosmological significance:

Governing with excellence can be compared to being the North Star: The North Star dwells in its place, and the multitude of stars pay tribute to it. ${ }^{55}$

Respecting the leaders and being beneficiaries of their virtuous rule, the people are happy to hand judgment over to their paternal overseers, the junzi and sages, regarding complex political and societal issues. Trusting in the government, they have no need to discuss affairs of the state themselves. The Confucian ideal is not an image of an authoritarian regime. The people do not complain but instead reap the benefits, feeling love towards the ruler who loves them in return. This is one aspect of Confucian exemplary paternalism.

\section{Legalism and Hard Paternalism}

Shin notes that Kongzi and his followers denounced the "exploitive practices of the military and purely legalistic forms of government, both of which were commonplace during his time. ${ }^{56}$ In the Confucian model, law takes secondary importance. ${ }^{57}$ Kongzi does not think that penal law is sufficiently able to procure a stable society that will be able to survive into the future. Kongzi says:

Lead the people with administrative injunctions (zheng) and keep them orderly with penal law (xing), and they will avoid punishments but will be without a sense of shame. Lead them with excellence $(d e)$ and keep

54 Bai, China, 17.

55 The Analects of Confucius, 2:1, 76.

56 Shin, Confucianism and Democratization, 107.

57 Fairbrother, “The Chinese Paternalistic State," 18. 
them orderly through observing ritual propriety $(l i)$ and they will develop a sense of shame, and moreover, will order themselves. ${ }^{58}$

$L i$ is an indispensable part of ren rulership, which will be explored in more detail in the following section. However, this passage shows that Kongzi is clear about the view that the people need to feel that a wrong action is immoral, not only that it leads to punishment if caught. The stability of society rests on the ideal that people will try to make the better decision in every circumstance (or at least more often than not), not only when they feel they are being watched. In contrast to positive and liberal paternalism that do not have strong deterrents in their system and methods, Shin tells us that Confucians "depend on their [the people's] aversion to losing face and being shamed as an effective deterrent to crime. ${ }^{59}$ This helps to build stable relationships in which people are honest, make good on their word and act through compassion.

The model that Kongzi offers contrasts with those thinkers (though coming after Kongzi himself) who have been identified as Legalists. These thinkers have a far more negative view than the Confucians of the moral capacities of people, of leaders, and on morality itself. The earliest political thinker to be categorized as a Legalist, Lord Shang (d. 338 все), believes that the basic disposition of people is that they covet wealth and fame and are afraid of punishments. When this is understood, the ruler can manipulate the people through rewards and punishment to act in ways that are for the greater good for themselves and others. Through the possibility of achieving rank and wealth, people will undertake the occupations that the state requires (in this case agriculture and military). They will follow and enforce the laws that the ruler initiates. Through fear of severe punishment, the people will not dare transgress the laws or pursue ends that are not sanctioned. However, we would argue that Lord Shang is not simply wishing to create a strong state with no care for the individuals that populate it. As Yuri Pines argues, in the thought of Lord Shang, "The people are simply unaware of what is to their ultimate benefit, so they are unable to maintain proper rule without active government intervention" and "Oppressive measures are needed simply to prevent the people from harming their own best interests." ${ }^{\prime 0}$ Lord Shang says that:

58 The Analects of Confucius, 2:3, 76 .

59 Shin, Confucianism and Democratization, 117.

6o Yuri Pines, "Legalism in Chinese Philosophy," The Stanford Encyclopedia of Philosophy (Winter 2018 Edition), ed. Edward N. Zalta, https://plato.stanford.edu/entries/chinese -legalism/ (accessed August 31st, 2020). 
They [the sages] set up law officers and government officials to be the authority, in order to guide them [the people]; and they knew that if the ten thousands of people all knew what to avoid and what to strive for, they would avoid misfortune and strive for happiness, and so restrain themselves. ${ }^{61}$

Although it may not be the case that all thinkers identified as Legalists hold to the principle of caring for and working in the best interests of the people, Lord Shang shows that Legalism is not incapable of having such principles.

It is interesting to note a similarity here between legalism and liberal paternalism. Although the two in many senses could not be further apart, both attempt to use the negative aspects of people's behaviors as tools to get them to act in certain ways. Confucianism, on the other hand, does not sanction such cynical methods.

This is the fundamental disagreement between Legalist and Confucian thinkers. The Legalists think that the majority of people are mostly selfish and cannot be cultivated. They must be brought in line through threat of punishment and incentive of reward. For Lord Shang, "the basis of the people is the law."62 He says: "if the basis is not solid, then people are like flying birds or like animals. Who can regulate these?"63 In this view, people who are allowed to base their decisions and actions on benevolence and virtue (most likely insincerely and for selfish reasons) are unpredictable and cannot be governed. The Confucians believe that people are capable of moral cultivation and can only be brought in line in a stable manner through adherence to higher moral principles, with law taking secondary importance. This is the case even where Confucian thinkers disagree as to what extent law and punishment should be enforced and used as a deterrent. Xunzi holds the stronger view in this regard, which does share some similarity with Legalist thinking. ${ }^{64}$

Kongzi would agree with Legalist thinkers that to perform acts of "benevolence" only for the benefit of oneself is not acceptable and recognizes that this is a problem endemic to the political institutions and the wider society. Kongzi says that it is "a disgrace to be wealthy and of noble rank when it [the way] does not [prevail in the state]." ${ }^{\prime 5}$ Sincerity in virtue and action, which the Legalists

61 The Book of Lord Shang: 'Shang Yang,' trans. J.J.L. Duyvendak (Ware: Wordsworth 1998), 242.

62 Ibid., 214.

63 Ibid.

64 For a discussion on the relationship between the use of law and virtue in the thought of Xunzi in comparison to the thought of Legalist thinker Han Fei, see Eirik Lang Harris, "The Role of Virtue in Xunzi's Political Philosophy," Dao 12, no. 1 (2013): 93-110.

65 The Analects of Confucius, 8:13, 123 . 
think is unlikely to be achieved by most, is the cornerstone of Confucian philosophy. Sincere moral and emotional sentiment towards those around you is paramount for a harmonious society.

Legalism can be described as a hard paternalism. The state is able to interfere in all aspects of people's lives and to forcefully bring them in line against their will. Legalism actively seeks to block the moral cultivation of the people. On the Legalist view, this is how peace and stability are to be found, creating a strong state militarily and agriculturally so that it benefits all the people. In comparison, Confucianism can be seen to be a soft paternalism but not simply in regard to the levels at which it sees intervention as justified. Confucianism is not arguing that Legalism is right in spirit only too brutal in its implementation. It fundamentally disagrees with its political model.

Nor does Confucianism simply offer rank and wealth as reward. Preceding the previous quote, Kongzi says, "It is a disgrace to remain poor and without rank when the way prevails in the state." ${ }^{\prime 6}$ This is because having authority of wealth and office in a benevolent government affords you more ability to help others and to further cultivate yourself through virtuous acts. The reward is in virtue itself, in the learning and cultivation, in the betterment of society. This reward can be earned without achieving high office. This method of governance that uses shame as a deterrent and virtue as an incentive is a soft form of paternalism but, as will now be seen as we move to explore the bottom-up political cultivation of the people, it is far-reaching and encompassing.

\section{The Vital Upward Movement of Exemplary Paternalism}

The unique strength of Confucian exemplary paternalism is in its upward momentum. Whilst the cultivation of the people is guided from above, it is informed by the moral sentiments of those below and asks the people to engage in their own betterment, even if in many cases this will be minimal. The system of moral cultivation can only exist if the people participate and serve in its larger body. The system gives birth to those virtuous enough to rule in the future. This is the only way to ensure lasting ren leadership in a society.

Confucianism makes no apology for the assumption (arguably at the heart of all paternalisms) that the common people are not automatically, simply by right of birth, sufficiently cultivated or knowledgeable enough to make the bigger society-wide decisions that will truly be to their benefit and the benefit of all. However, it is important to note that this is not a negative judgment on 
human nature (xing) in general. Kongzi allows for the possibility of universal education as he believes anyone can participate meaningfully in moral cultivation, even if most are not capable of becoming a junzi or sage. Mengzi has a view that human nature is inherently good. All people have the capacity to improve themselves through reflection and cultivation. It is just the case that in reality most people do not. ${ }^{67}$

Xunzi takes an opposing view to Mengzi and does not regard human nature to be inherently good. However, Xunzi still recognizes that "The $[j u n z i]$ is by birth no different from any other man; it is just that he is good at making use of things." ${ }^{\prime 8}$ This echoes a passage from The Analects:

The Master said: 'Human beings are similar in their natural tendencies (xing), but vary greatly by virtue of their habits.' ${ }^{\prime 6}$

As mentioned earlier, an important part of ren rulership is $l i . L i$ is a key tool in the cultivation of the people. It has a broad scope of meaning. It can refer to rituals and ceremonies, codes of conduct in society, and the concrete instantiation of those codes in daily life. ${ }^{70}$ In the Analects, some of the rituals predominantly discussed include "ceremonies of ancestor worship, the burial of parents, and the rules governing respectful and appropriate behavior between parents and children." ${ }^{71}$ Xunzi tells us that li reinforce the distinctions between people of different roles and social standing that are to be observed within the hierarchy of society and the family. ${ }^{72}$

$L i$ are the outward manifestations of what are understood to be our internal moral sentiments. ${ }^{73,74}$ Respect shown to one's parents, care and love shown to one's children, these are manifestations of compassion that have been inscribed in the li by exemplary rulers of the past. On their own, li are empty

67 Paul R. Goldin, "Xunzi," The Stanford Encyclopedia of Philosophy (Fall 2018 Edition), ed. Edward N. Zalta, https://plato.stanford.edu/entries/xunzi/\#HumaNatuXing (accessed August 31st, 2020).

68 Xunzi, 16.

69 The Analects of Confucius, 17:4, 203.

70 Lai, An Introduction to Chinese Philosophy, 25.

71 David Wong, "Chinese Ethics," The Stanford Encyclopedia of Philosophy (Summer 2020 Edition), ed. Edward N. Zalta, https://plato.stanford.edu/archives/sum2o2o/entries/ ethics-chinese/ (accessed August 31st, 2020).

72 Xunzi, 94.

73 Bai, China, 31.

74 Xunzi disagrees with this and views li more as artificial constructions of the sages that serve to rectify the harmful desires of the people. However, even Xunzi recognizes the natural feelings of joy and sorrow that underpin rituals. See Xunzi, 105-106. 
gestures. When accompanied by the appropriate moral sentiment they are moral acts that allow for a person to grow in virtue and knowledge. Sigurdsson explains the $l i$ "function as pedagogical forms of behavior and gestures that entail both the interpersonal respect necessary for successful associated living and facilitating growth and development in the individual." ${ }^{75}$ By adhering to the $l i$, people are learning and practicing virtuous behavior.

It is only those who truly understand the li and their relationship to virtue that can themselves initiate new practices or change existing li. If the li are controlled and altered by those who do not understand them (and therefore do not truly understand human moral sentiments), society will crumble. ${ }^{76}$ For Kongzi, the one who truly understands ren and li will be able to govern the people with ease. ${ }^{77}$

It is the family that Kongzi sees as the arena in which to cultivate the root of ren in order that it may become ubiquitous. The li are implemented and controlled from above, yet as manifestations of innate moral sentiments, they are grown from the bottom. The rulers are understood as the fathers and mothers of the people, caring for their children and helping them to practice the virtues that underpin $l i$ and to blossom within the ritualized manifestations of those virtues.

For the early Confucians there is a stress on the virtue of xiao (filial piety). Filial piety is shown in respect and loyalty to one's elder siblings, parents, elders, and superiors. The junzi, having long cultivated xiao, will show respect and loyalty to the ruler. Even the sage ruler shows great respect and loyalty to his ancestors and the rulers of the past. ${ }^{78}$ Within exemplary paternalism there is a continuous respect and loyalty paid upwards via each station from those at the bottom of the hierarchy to those at the very top and beyond. This upward looking respect is also returned with care and love to those below. The relationship is reciprocal but not equal.

Despite the general hierarchical nature of this structure, loyalty to one's elders and superiors cannot be understood as an unquestionable allegiance. This is a misunderstanding of Confucian paternalism as straightforwardly topdown and authoritarian. $L i$, having been created over many years by sage rulers who understand them cannot be changed lightly. This is also the case within the family. Kongzi says, "A person who for three years refrains from reforming

75 Sigurdsson, "Confucian Philosophy," 22.

76 The Analects of Confucius, 16:2, 196-197.

77 Ibid., 3:11, 85 .

78 Ames and Rosemont, "Introduction," 64. 
the ways of his late father can be called a filial son."79 But reform here is still possible and even expected. A child may remonstrate softly with their parents. ${ }^{80}$ Tan highlights that Kongzi "not only did not advocate unquestioning obedience to those in authority, but actually considered it very dangerous for rulers to desire and enjoy unquestioning obedience."81 Tan points to chapter 13:15 of the Analects in which Kongzi is asked if there is any one saying that can ruin a state to which he replies:

... there is a saying, 'I find little pleasure in ruling, save that no one will take exception to what I say.' If what one has to say is efficacious and no one takes exception, fine indeed. But if what one has to say is not efficacious and no one takes exception, is this not close to a saying ruining a state? ${ }^{82}$

The responsibility of the moral development of individuals is not necessarily solely in the hands of the state. $L i$ is given to the people so that they can use it to cultivate themselves and others around them. Sometimes this means inferiors remonstrating and reforming their elders.

A conversation is given in the Analects:

The Governor of She in conversation with Confucius said, 'In our village there is someone called "True Person." When his father took a sheep on the sly, he reported him to the authorities.' Confucius replied, "Those who are true in my village conduct themselves differently. A father covers for his son, and a son covers for his father. And being true lies in this." ${ }^{83}$

This passage can serve to highlight many aspects of Confucianism. We see here that law is not promoted by Kongzi as the correct way to deal with the situation of stealing a sheep (though this is not to say it may not be required in a more serious situation). Those who consider the man who handed his own father over to the authorities as superior in moral virtue, understanding it as a selfless act in honor of the greater good, are mistaken. Obeying the law (particularly to earn the title of "virtuous") is not as important as loving and caring for one's

79 The Analects of Confucius, 1:11/4:20, 74.

8 o Ibid., 4:18, 93 .

81 Tan, "Authoritative Master Kong," 143.

82 The Analects of Confucius, 13:15, 166.

83 Ibid., 13:18, 167. 
family. ${ }^{84}$ To act in a way contrary to the natural love one feels for their family is not the behavior of a virtuous person.

However, this love towards one's father cannot be displayed in simply covering up the crime and being complicit in it. This would also not be virtuous behavior. Bai explains that by "preserving the loving relationship and trust, one can then more effectively help him [the father] right his wrongs." ${ }^{85}$ Helping the father to right his wrongs will be more beneficial to the father and to society at large. This will not be a specific response to the crime as a legal framework would likely produce. Situations are contextual and need to be approached with creativity. Kongzi says, "I do not have presuppositions as to what may and may not be done."86 Sigurdsson explains that "With regard to $l i$, a person who has successfully internalized the spirit of a certain ritualistic practice is capable of applying it spontaneously when responding to new circumstances by adapting its primary or initially 'stylized' movements to these very circumstances."

Another key aspect here is that it is possible for the son to be the more morally cultivated out of the two in the relationship between him and his father. Therefore, Confucianism is realistic about accepting the non-ideal reality that those who hold inferior positions in government can be more virtuous than those above. It is even the case that those who are not in the government can be more virtuous than those who are.

In cases where such exemplary rulership is lacking, Kongzi looks to the sage rulers of the past and seeks to recruit the young men of his time to adopt the li crafted by these exemplars. Through this they will become learned in the rituals and behaviors and instill themselves with great virtue and benevolence. They will be able to take more responsibilities and higher office in which they are able to benefit more people and to cultivate their virtue further still. Over time, when they reach the highest offices it is hoped that they will have true understanding of ren and $l i$ and the authority to be able to transform them and shape them to fit the changing reality and relationships between the people.

Sigurdsson argues that in early Confucianism, "In order to be truly successful, the individual, after having matured, also needs to have developed and be able to apply critical and creative powers to facilitate the continuous adaptation of tradition to the circumstances and direction of the incessantly evolving times. ${ }^{88}$ Confucianism does not recommend dogmatic adherence to tradition.

\footnotetext{
84 Bai, China, 39.

85 Ibid., 40.

86 The Analects of Confucius, 18:8, 216.

87 Sigurdsson, "Confucian Philosophy," 31.

88 Ibid., 29.
} 
Sigurdsson points to two key passages to make this argument. In the Analects, Kongzi says, "Reviewing the old as a means of realizing the new - such a person can be considered a teacher." ${ }^{89}$ In the Zhongyong (another Confucian text), Kongzi warns that those who are "born into the present age and yet return to the ways of the past will cause themselves misfortune."90

But it is not only the young who are cultivated this way. O'Dwyer recognizes that in classical Confucianism:

... Anyone who lives a reasonably full life will get his or her chance to acquire knowledge of, and act beneficently for, the good of others across different relationships. This point will hold for both men and for women in any kind of role in which they deliberate for the good of others, such as younger siblings or their children. An exemplary person or sage like Confucius or Mencius would stand out, however, in his cultivated abilities as parent, scholar, teacher, or minister to realize the widest range of moral and material goods for others. ${ }^{91}$

O'Dwyer's description highlights that a Confucian morality based on familial relations seeks to instill paternal behaviors towards others into the whole of society. This allows the people to cultivate themselves in the ways that will possibly allow them to become virtuous paternal rulers of the future. For most, even in the ideal society, moral cultivation would only amount to being a good family member, a non-disruptive member of the community and perhaps an agricultural contributor. However, the people make up the system and enact the rulers wishes, propagating and instilling the morality issued from above and willingly providing the labor that secures the material needs of the people. Kongzi says, "Just being filial to your parents and befriending your brothers is carrying out the work of government." ${ }^{\text {92 }}$

As O'Dwyer highlights, the li that are in use during the time of Kongzi give much more power to men than women. This is a continuation of the preceding tradition and again can lead some to claim Confucianism as authoritarian in forcing some into subservience whilst granting authority and power to others. As stated earlier, O'Dwyer leans towards this view. This is a problem for classical Confucianism, but it is also a misunderstanding of the philosophy. $L i$ can, and must, be reformed to reflect the changing nature of society

89 The Analects of Confucius, 2:11, 78.

$90 \quad$ Zhongyong, § 28, quoted in Sigurdsson, "Confucian Philosophy," 29.

91 O'Dwyer, "Epistemic Elitism," 40.

92 The Analects of Confucius, 2:21, 80. 
and its role relations. It is only the underlying moral sentiments, the natural roots from which virtue grows, that are seen to be constant. As Shin explains, "Kongzi viewed government as a dynamic phenomenon dealing with the constantly shifting relationships between the governor and the governed."93 It is in a stable society that propagates continuance of tradition and a respect for what came before that people can learn to become virtuous and then go on to transform that tradition. Revolution that seeks to overthrow and destroy the past misunderstands the nature of progression. There is no final aim or hard culture that is to be achieved, it is an ongoing process constantly improved. As Sigurdsson argues: "While certainly foundational in some sense, tradition is understood as a path to be constantly forged rather than as a place to be discovered once and for all." ${ }^{94}$ Confucian exemplary paternalism is an ongoing constantly evolving process that expressly engages those at the bottom, society as a whole, as active participants in the general improvement of society.

A definition of paternalism that focuses on the substitution of judgment instead of use of force allows for a fruitful exploration of Confucianism through the lens of paternalism. This focus draws out interesting aspects of Confucianism and helps us to understand the system of the cultivation of the people and its relationship to the rule of the exemplars. What we have called Confucian exemplary paternalism is seen to be non-authoritarian in a variety of ways and so can help to remove the inherent negative connotations of paternalism. It does not accept the force of law as a sustainable or necessary method for encouraging the people to act in ways that are to their benefit and the benefit of wider society. The authority of those who are superior is based on merit and does not demand unquestioning obedience. It relies on the people to become cultivated in order that they make better decisions for themselves without the state prescribing definitive ways to act in every situation. The system inherently requires adaptation to new and changing circumstances and encourages innovation in governance.

We have explored different definitions and models of paternalism in this paper, but all are grounded on the idea that, at least sometimes, the majority of people are not able to act in their best interests through lack of knowledge or perhaps motivation. One of the most unique aspects of Confucian exemplary

93 Shin, Confucianism and Democratization, 107.

94 Sigurdsson, "Confucian Philosophy," 23. 
paternalism is that this principle does not lead simply to a hard dichotomy between rulers and ruled (or those who know better and those who do not). Instead, Confucianism seeks to rectify the problem of the people's less than beneficial behaviors by giving them the knowledge and tools to cultivate themselves and others around them.

This creates a self-supporting system in which the exemplary paternal rulers craft the li (that are based on the innate moral sentiments of the people) in order to give them the tools to cultivate themselves as paternal members of society, which in turn will produce the exemplary paternal rulers of the future. These leaders will then continue to evolve and perpetuate the system creating a new generation of paternal citizens. A child is still born lacking knowledge and virtue (unable to act in their own best interests) but is born into a society in which the $l i$ will shape and mold them into a caring, virtuous member of society.

Our reading of Confucianism as a form of paternalism shares many similarities with Joseph Chan's reading of Confucianism as a model of "perfectionism." Indeed, we agree with Chan's ideas at several points in this paper. Chan defines perfectionism in its broadest sense as "the view that the state should promote valuable conceptions of the good life."95 Our reading is in line with Chan who notes that within the ideal conception of Confucian perfectionism is included "governance by people who are virtuous and competent; moral edification by example and persuasion; rites as a method of socialization and governance; and benevolent rule to ensure material sufficiency for all people." ${ }^{\prime 96}$ Like Chan, we also wish to stress that:

Effective governance based on benevolence is only one aspect of the Confucian ideal. Another is the moral development of the common people, namely, that they should be encouraged to act virtuously in the spirit of harmony, righteousness, benevolence, and deference. ${ }^{97}$

However, Chan states that paternalism is not an appropriate term to apply to Confucianism due to the common association of paternalism with use of force and coercion. Chan states that:

95 Joseph Chan, "Legitimacy, Unanimity and Perfectionism," Philosophy and Public Affairs 28, no. 1 (200o): 5 .

96 Chan, Confucian Perfectionism, 2.

97 Ibid., 11. 
Perfectionism in politics, however, does not necessarily carry this feature, and in fact many contemporary political perfectionists do not favor coercion as a means to promote the good life. ${ }^{98}$

Clearly, this perspective directly conflicts with one of the main points of our paper, namely, to show that the definition of paternalism should be expanded to include its more subtle and softer forms. We see Chinese philosophy in general, and Confucian philosophy in particular, as playing a crucial role in this endeavor. In fact, Chan himself shows the difficulty of maintaining an entirely non-paternalist reading of Confucianism when he refers elsewhere to the relevance of paternalist thinking for understanding aspects of the Confucian hierarchy. ${ }^{99}$

Our work is in fact similar in goal to Chan who wishes to demonstrate that Confucianism being a form of perfectionism does not inherently entail authoritarianism, as seen in the quotation above. Another reason Chan sites for preferring perfectionism to the label of paternalism is that he rejects the common reading that within Confucianism "the principles governing political relationships are drawn from, or are the same as, the principles governing the relationships in the family." ${ }^{100}$ Whilst Chan provides some interesting insights into the differences between the relationship of the ruler and the ruled and the father and son, which we do not have sufficient space to explore here, we would favor the more widely endorsed view that the morality of the Confucian state extends outwards from the model of the family. By retaining the idea of the continuation of the familial relations into the political realm, we are able to argue for and to elucidate the upward movement of Confucian paternalism and its relation to the political and social structure. This is because in an ideal Confucian society, moral cultivation is taking place at every social level from the most intimate setting of the family to the widest context of rulership. This is the multileveled structure of Confucian paternalism in which, ideally speaking, all citizens are participants.

More simply put, Confucianism suggests that a good upbringing in a stable family life with positive role models, coupled with a good education, is conducive to producing morally upstanding citizens who will be able to leave society a better place than they found it. This is a common notion in most societies.

\footnotetext{
98 Ibid., 44 .

99 Joseph Chan, "Exploring the Nonfamilial in Confucian Political Philosophy," in The Politics of Effective Relations: East Asia and Beyond, eds. Hahm Chaihark and Daniel A. Bell (Lanham: Lexington Books, 2004), 56/62.

100 Chan, "Exploring the Nonfamilial," 55.
} 
However, Kongzi realizes the power of this idea and therefore creates a model of paternalism in which the primary duty of the government is to ensure the stability, continuation, evolution and improvement of this societal structure. Therefore, Confucian exemplary paternalism can give great insight into how paternalist methods of governance can be utilized in modern societies where paternalist methods of oversight are indeed common.

As $l i$ is an indispensable part of exemplary paternalism, we agree with Sigurdsson who argues that:

There are numerous interpersonal customs in various Western traditions that can be formulated and applied in a manner comparable to $l i$. Their increased formalization and explicit 'inculcation' would, I suggest, have a beneficial impact on both individual and society as long as the critical and creative attitude that their mastery requires is not left out of the picture. ${ }^{101}$

To be clear, this is not to argue for the installation of a full model of Confucian exemplary paternalism. We have not dealt with the difficult issues that arise in such a concrete implementation, particularly what methods should be employed when discord between the rulers and people arise. This is a topic for further study. Here, we simply wish to show that Confucianism can offer valuable insight into debate surrounding paternalism.

Confucian exemplary paternalism is not so vulnerable to the critiques that other contemporary soft forms of paternalism are. Positive and liberal paternalism can be charged on the grounds that their scope is limited and cannot provide answers to the more difficult questions of governance. This limitation is directly related to attempts in the models to avoid the use of state coercion. Confucianism is not open to this criticism as it is a system that is far reaching and is in many ways an overhaul of people's way of life. It is not attempting to alter people's decision making in only limited regards. It is a system of inculcating the people into a moral outlook that carries over into every event of decision making of the general populace. In fact, rather than being accused of being too limited in scope, an argument can be made that is even more totalitarian than its legalist counterpart. Whereas Legalism asks that you act in a certain way, Confucianism asks not just for physical obedience but also obedience of the heart and mind. ${ }^{102}$ We do not make that criticism here and

\footnotetext{
101 Sigurdsson, "Confucian Philosophy," 31.

102 Hans-Georg Moeller and Paul J. D'Ambrosio, Genuine Pretending: On the Philosophy of the Zhuangzi (New York: Columbia University Press, 2017), 47-48.
} 
much of what we have argued goes against this view (particularly in regards to obedience).

Confucian exemplary paternalism is not authoritarian. It seeks to align itself with the will of the people. Although not democratic, it seeks to be representative of the natural moral inclinations of the people and to inspire these same sentiments. Unlike liberal paternalism, Confucianism is transparent in its methods. The people understand the government is asking the people to better themselves. Confucianism retains a deterrent against bad behaviors in the form of shame. It offers the rewards of virtue itself and a better life for the individual and society.

The differences between Confucian exemplary paternalism and contemporary models of soft paternalism mean that Confucianism has a lot to offer current debate regarding definitions. Its resilience in the face of criticisms that are levelled at soft models of paternalism mean that it can be relevant towards contemporary applications. Paternalism, in the Confucian model, is not a topdown system of governance that stops the people from doing what they want but rather a training ground that allows the people to flourish.

\section{Biography}

Dr. Sarah Flavel is a Reader in Asian and Comparative Philosophy at Bath Spa University, UK. Her current research focuses on Chinese and comparative philosophy. She is Vice-President of the Society for Asian and Comparative Philosophy and she is Associate Editor for Comparative and Continental Philosophy (Taylor and Francis Journals). Her recent work has appeared in Philosophy East and West (u Press) and Dao (Springer).

Brad Hall is a PhD candidate at King's College London, UK. His current research project is entitled The Zhuangzi: A Critical Encounter with Conceptual Metaphor Theory. He has published work in Frontiers of Philosophy in China (Brill) and Dao (Springer). 